\title{
Intensive moose browsing and small-scale domestic woodcutting impacts on forest successional trajectories in Gros Morne National Park, Canada
}

\author{
by Shannon White ${ }^{1}$, Xinbiao Zhu ${ }^{2 *}$, Fanrui Meng ${ }^{1}$, Scott Taylor ${ }^{3}$, and Charles P.-A. Bourque ${ }^{1}$
}

\begin{abstract}
Moose (Alces alces L.) browsing in Gros Morne National Park has damaged its balsam fir (Abies balsamea (L.) Mill.)dominated forest. A forest estate model was used to evaluate (i) the impacts of moose browsing and woodcutting on forest succession and (ii) strategies of forest restoration through planting and moose population management. The simulation results show that under current heavy browsing pressure growing stock of balsam fir decreases by $38 \%$, but the area of spruce (Picea mariana (Mill.) BSP and P. glauca (Moench) Voss) increases by 32\% over a 100-year planning horizon, compared to that under light browsing scenario which is assumed to be similar to the forest outside the Park due to moose population management. Annual allowable cut (AAC) for the Park's 19400 ha domestic harvest area is estimated to be around $120979 \mathrm{~m}^{3}$ in a light browsing scenario, $21 \%$ higher than the sustainable harvest level in a heavy browsing scenario. The model forecasts a 97\% reforestation of the Park's 7194 ha disturbed area by planting in the heavy browsing scenario, leading to an increase in total forest growing stock by $22 \%$ and AAC by $12 \%$. Integration of planting with moose population management could be a more efficient way of restoring forest under high browsing pressure in GMNP.
\end{abstract}

Keywords: balsam fir, browsing, domestic harvest, forest-estate model, moose population density, planting, scenario analysis, spruce, stocking

\section{RÉSUMÉ}

Le broutage intense que font les orignaux (Alces alces L.) dans le parc national du Gros Morne y ravagé les forêts à dominance de sapin baumier (Abies balsamea [L.] Mill.). On a eu recours à un modèle de simulation forestier pour évaluer (i) l'impact du broutage des orignaux et de la récolte de bois sur la succession et (ii) les stratégies de régénération forestières par reboisement combiné à un contrôle des populations d'orignal. La simulation a révélé que, sous la forte pression actuelle résultant du broutage, le stock de sapin baumier diminuait de $38 \%$ en faveur des épinettes (Picea mariana [Mill.] BSP et $P$. glauca [Moench] Voss) dont la superficie s'accroissait de $32 \%$ sur un horizon de planification de 100 ans comparativement à la situation prévalant sous un niveau de broutage léger comme celle prévalant à l'extérieur du Parc en raison à la faveur d'une gestion de la population d'orignaux. On estime à $120979 \mathrm{~m}^{3}$ la possibilité annuelle (AAC) coupe locale pour les 19400 ha du Parc avec un niveau de broutage léger, soit $21 \%$ de plus que le niveau durable avec un scénario de broutage intense. Le modèle prévoit la plantation d’arbres sur $97 \%$ des 7194 hectares perturbés par le broutage dans le Parc permettant ainsi de hausser le stock en croissance de $22 \%$ et de $12 \%$ la possibilité forestière. La combinaison du reboisement et du contrôle des populations d'orignaux permettrait de restaurer plus efficacement la forêt soumise à une forte pression de broutage dans le PNGM.

Mots-Clés : sapin baumier, broutage, récolte domestique, modèle de simulation forestier, densité des populations d'orignal, reboisement, analyse de scénarios, épinette, densité relative (stocking)

\footnotetext{
${ }_{1}^{1}$ Forestry and Environmental Management, University of New Brunswick, Fredericton, NB, Canada, E3B 5A3

${ }^{2}$ Natural Resources Canada, Canadian Forest Service - Atlantic Forestry Centre, Corner Brook, NL, Canada, A2H 5G4

*Corresponding author: Xinbiao Zhu (xinbiao.zhu@canada.ca)

${ }^{3}$ Parks Canada, Gros Morne National Park, Rocky Harbour, NL, Canada A0K 4N0
} 


\section{Introduction}

Moose browsing can alter species composition of forest communities, successional pathways, nutrient cycling, and ecosystem productivity (Jeffries et al. 1979; McNaughton 1979; Hobbs et al. 1991; Paster et al. 1997). Large herbivores have been shown to change landscape-level processes by altering the regeneration success of forest species (Mathisen et al. 2017), which in turn can alter species abundance and steer species changes at the landscape level (Milligan and Koricheva 2013). The impact of moose is a serious management concern to Gros Morne National Park (GMNP) that has been struggling to maintain the ecological integrity of the entire ecosystem in the park (Gosse et al. 2011).

GMNP is located on the west coast of the island of Newfoundland. Its $992 \mathrm{~km}^{2}$ balsam fir-dominated forest plays a critical role in preserving local biodiversity, providing a wide range of habitats for plants and animals alike, but currently suffers significant moose browsing damage. Gros Morne is a unique national park with a mandate to manage the ecological assets of the park, while supporting domestic harvest programs for residents within the park boundaries. The domestic timber harvest program was developed based on the 1973 park establishment agreement, which has allowed park residents (up to two generations) to extract wood for personal use such as for building homes and boats and heating homes (McCarthy 2000; Parks Canada 2005). Small-scale domestic harvesting activity occurs within 12 designated cutting blocks and has created small, isolated clear-cuts within the blocks that, when combined with historical large-scale insect disturbances, have resulted in a mosaicked landscape of different forest successional pathways. This unique landscape is favourable habitat for moose by providing suitable food and shelter, and unintentionally promotes the unconstrained moose population growth in the area (Connor et al. 2000). Under such circumstances, maintaining and restoring ecological integrity within the context of heavy moose browsing in parks is a significant philosophical shift in park management for many park managers (Sy et al. 2009).

Moose were first introduced to the island portion of Newfoundland and Labrador in 1878, and again in 1904 (Pimlott 1953). Since then, the moose population has swollen to cover the entire island portion of the province, including Gros Morne and the northern Peninsula by the late 1940s (Caines and Deichmann 1989). Moose populations have been shown to increase rapidly, especially in the absence of hunting and limited natural predation (Murie 1934; Pimlott 1953). The extinction of the Newfoundland wolf (Canis lupus L.) in the early part of the $20^{\text {th }}$ century (Pimlott 1959; Furgeuson and Messier 1996) and reductions in black bear (Ursus americanus Pallas) populations created a situation in GMNP where moose population growth was practically unconstrained from predation (McLaren et al. 2009). Low predation rates and termination of hunting in 1974, together with high forest-regeneration levels following regional outbreaks of spruce budworm (McCarthy and Weetman 2007), led to a rapid expansion of the moose population during the 1980s and 1990s (Janes 1976; Taylor 1991). The moose population increased from approximately 270 individuals in 1971, to well over 7000 in 1998, making it one of the highest moose densities anywhere (McLaren et al. 2004). Mawhinney and Mahoney (1994) had warned that the population density had reached the park's maximum habitat carrying capacity at that time. In general, the increase of browsing damage by moose with hyper-moose population density in the past several decades has severely affected park ecosystem integrity and forest regeneration (Zhu et al. 2010; Gosse et al. 2011). Moose populations began to slowly decline in the early 2000s, particularly in the park highlands (Thompson 2007), but intense browsing continued to limit forest regeneration. Park managers implemented an annual hunt, beginning in 2011, to reduce the population to more sustainable levels. As of 2019, there were approximately 2160 individuals mostly in the lowland, productive forests of the park. Maintaining moose population numbers remains a significant challenge for GMNP managers in their mission to safeguard forest ecosystem functioning and services throughout the park.

At GMNP, moose have consumed nearly all their preferred browse species, including Canada yew (Taxus canadensis Marsh), mountain maple (Acer spicatum Lam.), mountain ash (Sorbus americana Marsh), northern wild raisin (Viburnum cassinoides L.), and have progressed to target balsam fir (Abies balsamea (L.) Mill; Connor et al. 2000; Humber et al. 2009). Repeated heavy browsing on balsam fir seedlings has greatly reduced balsam fir regeneration levels, leading to a proliferation of non-palatable shrubs and herbs and a subsequent increase in balsam fir regeneration suppression (Gosse et al. 2011). Without intervention, about 37-45\% of balsam fir is expected to be replaced by low-density black spruce and grasses in the next century (Zhu et al. 2010). At high browsing levels, where the density of balsam fir in the understorey is low and seed sources have been severely degraded, supplemental planting is seen as the only option to restore natural forest ecosystems (Gosse et al. 2011). In Nova Scotia's Cape Breton Highlands National Park, managers have concluded that, due to hyper-abundance of moose, forested ecosystems will not recover without human intervention, including moose population control and reforestation (Smith et al. 2015).

Trees damaged by browsing can respond in several ways (Kalen 2006). Increased moose densities and the resulting increase in browsing has been shown to negatively impact tree height growth (Bergeron et al. 2011). Within stands, tree heights can be quite variable under heavy browsing, with an overall impact of decreasing biomass in affected stands (Mathisen et al. 2017). Forests within the park are currently not producing volume growth at the same rate or at the same level as stands with low moose-browsing levels. This observation was communicated to be an important limitation of a prior study by Zhu et al. (2010).

Due to complexities in forest ecosystem responses to variable moose browsing, simply performing an analysis on existing datasets may not lead to a decisive resolution of the problem. Forest models have the benefit of being able to generate multiple realistic, and even hypothetical, scenarios to allow comparison between different management strategies (Pretzch et al. 2008). Linear programming (LP)-based forest management models have been used to estimate impacts of management decisions and disturbances on forest develop- 
ment and design optimum forest management scenarios (Gustafson and Crow 1996; Cieszewski et al. 2004). Forest management models require accurate representations of forest ecosystems by appropriate stratification of forest community types and age classes (Remsoft 2016). The forest management model also requires a growth and yield component to estimate how the forest develops over time based on different indicators, such as merchantable volume, carbon, and stock and habitat suitability for wildlife (Gustafson and Crow 1996; Vanclay 2002; Tomppo et al. 2008; Shifley et al. 2017). The accuracy of forest management models is governed by the accuracy of inputs being used to describe and predict the forest dynamics in response to different management prescriptions (Shifley et al. 2017). In previous studies in GMNP, yield curves and forest transition rules were developed based on data from adjacent provincial forests due to lack of forest inventory survey and sampling plots within the park (Zhu et al. 2010). In provincial forests, moose browse was much less intense compared with the national park due to hunting regulations and available silvicultural treatments to enhance regeneration levels on disturbed sites (Robert Sutton, NLDNR personal communication 2016). Researchers were aware of the problem that provincial yield curves and transition rules could possibly diminish credible accounting of the impact of heavy moose browsing on forest regeneration success within the park. In the past few years, intensive field sampling surveys were conducted to create GMNP-specific yield curves and transition rules. Based on the implementation of a state-of-the-art forest-estate model, the objective of this study was to conduct a scenario analysis using the latest forest inventory and field survey data to assess: (i) moose browsing and domestic harvest impacts on park-forest development; and, (ii) forest restoration strategies by simulating programs of moose population control and reforestation.

\section{Methods}

\section{Study area}

Gros Morne National Park $\left(1805 \mathrm{~km}^{2}\right)$ is a UNESCO World Heritage Site, located on the western coast of the island of Newfoundland $\left(49^{\circ} 41^{\prime} 22^{\prime \prime} \mathrm{N}, 57^{\circ} 44^{\prime} 17^{\prime \prime} \mathrm{W}\right)$. The park provides a wide range of habitats for over 700 species of flowering plants and 400 species of bryophytes, 239 species of birds, and 14 species of mammals (Government of Canada 2010). The land base stretches from coastal lowlands dominated by bogs and shrub forestland, to the alpine plateau sparsely covered by forest heath and shrub barrens, with small forest patches in sheltered valleys. There are three ecoregions by distinct physical and biological factors, within the GMNP. The western ecoregion is characterized by a humid climate and is typically good for forest growth. The northern ecoregion normally has lower precipitation and air temperatures, with a shortened growing season. The Long Range Barrens ecoregion includes elevated areas above the treeline (Meades and Moores 1994). Productive forest stands are found on the transitional slopes between the coastal plains and alpine plateau and represent $55 \%$ of the park's land base. The forest is comprised of primarily balsam fir and white birch (Betula papyrifera Marsh.), with lesser amounts of black spruce white spruce, yellow birch (B. alleghaniensis Britt.), red maple
(Acer rubrum L.), trembling aspen (Populus tremuloides Michx.), white pine (Pinus strobus L.), and tamarack (Larix laricina (Du Roi) K. Koch). Regional climate is controlled by prevailing southwesterly winds that blow onshore from the Gulf of St. Lawrence, resulting in cool summers (July mean temperature of $\left.15^{\circ} \mathrm{C}\right)$ and mild winters $\left(-7.5^{\circ} \mathrm{C}\right)$, with 1200 $1450 \mathrm{~mm}$ of rain (Humber 2009) and $328 \mathrm{~cm}$ of snow (Zhu et al. 2010).

Fire has a limited control on forest development in western Newfoundland due to the region's humid maritime climate (Meades and Moores 1994; Engelmark 1999). Recurring insect outbreaks have been the primary natural stand-replacing mechanism in this region. For example, a spruce budworm (Choristoneura fumiferana Clemens) outbreak in 1977 and hemlock looper (Lambdina fiscellaria Guen.) in 1969, 1988, and 1996, affected large tracks of forests in the region (Bergeron and Leduc 1998; Bouchard et al. 2005; McLaren et al. 2009). As evident in the forest inventory, wind is also an ever-present natural disturbance in GMNP. Wind-driven disturbances have created a landscape with small stand-level openings driven by recurring small-scale wind events, and occasional large blowdown patch sizes averaging 7.4 ha and ranging up to 70.8 ha created by severe windstorms.

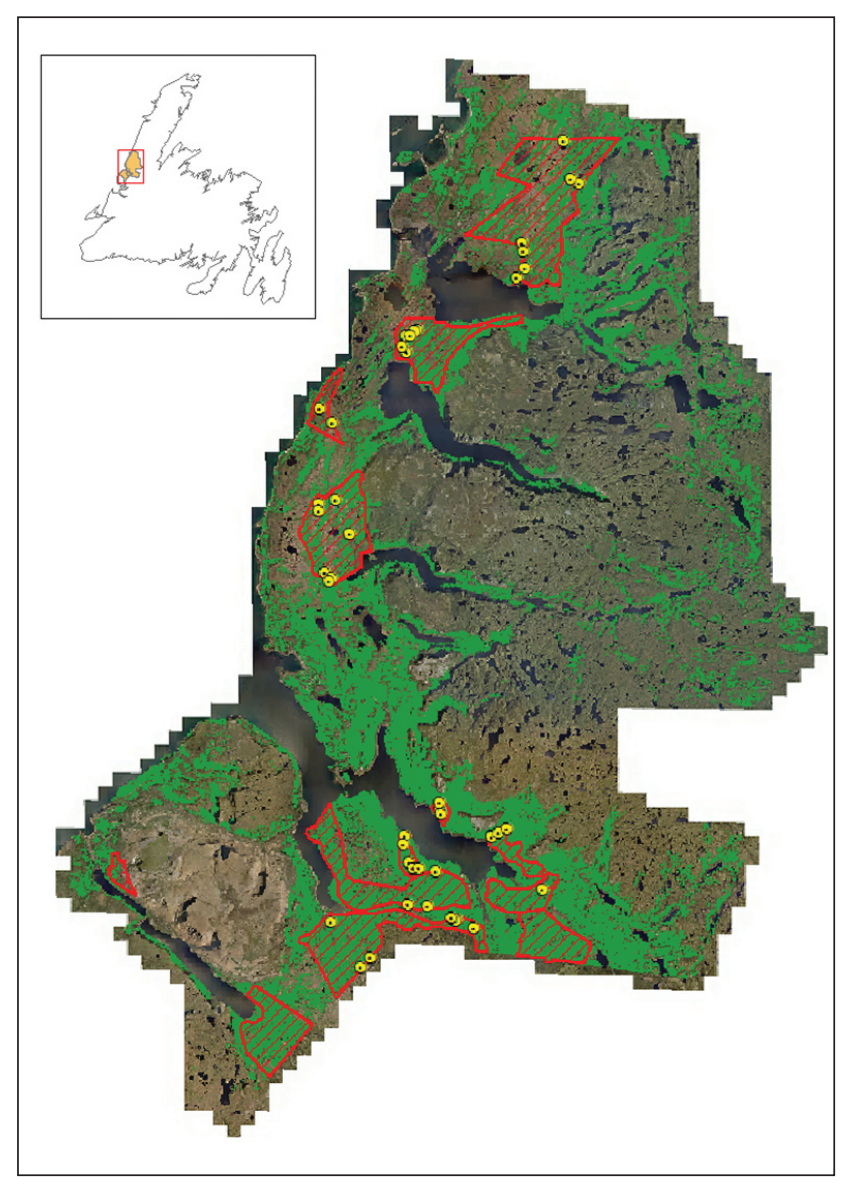

Fig. 1 Locations of GMNP domestic harvest blocks (red) displaying their positions within the productive forest zone within the park. Regeneration-survey plots are yellow dots. 
The park's domestic harvesting program involves 12 harvest blocks or 19400 ha of productive forests, approximately $25 \%$ of the park's land base (Fig. 1). Past harvesting rates (1993-2015) within the park are quite variable with an average historical harvest level of approximately of $313 \mathrm{~m}^{3}$ year-1.

In an effort to reduce moose populations, park managers initiated a moose hunting program in 2011, which has continued each year to the present and has expanded from a small pilot area in 2011 to include almost the entire park. The effort has resulted in nearly 4100 moose taken from inside the park during that time period.

\section{Forest management modelling}

Remsoft's Woodstock ${ }^{\mathrm{TM}}$ was used to evaluate the combined effects of moose and domestic harvesting and to optimize management strategies with a focus on restoring forest integrity within the park. Woodstock ${ }^{\mathrm{TM}}$ is a standard forestmodelling tool used by forest industry and government agencies for long-term forest management planning and wood supply analysis across Atlantic Canada. The key model inputs (i.e., transition rules, yield curves, and description of the forested land base derived from datasets ranging from forest regeneration surveys, growth and yield data, and GIS-based forest inventories) along with forest management actions and disturbances determine forest-development dynamics.

\section{Transition ruleset}

To build forest transition rulesets for the model, regeneration plots were classified into forest community types according to GIS-based forest inventory and pre-disturbance seedling and sapling counts. Stocking levels were calculated for each plot and then summarized by forest community types, corresponding with western and northern ecoregions.

Regeneration surveys were conducted in the disturbed areas of productive forests during June-August 2016 (Fig. 1), following the Newfoundland and Labrador Regeneration Assessment Procedures and Alberta Regeneration Survey Manual (Department of Natural Resources 1993). Stocking rate, tree height, and damage of dominant stems were measured to assess regeneration and browsing damage among the different tree-age classes in the park. Presence or absence of native tree species (e.g., white spruce, black spruce, balsam fir, white birch, yellow birch, red maple, white pine, tama- rack, or trembling aspen) was also recorded. At each plot location, a visual survey for moose damage on individual stems was conducted. If moose damage was observed, the height of damage on affected stems was recorded, as well as an estimate of distance and direction of the nearest healthy tree that could serve as a good seed source to foster future forest growth.

\section{Forest growth and yield curves}

Yield curves were generated by applying the Newfoundland and Labrador Provincial Growth and Yield Tool (NLGY) that uses a combined exponential and power function regression analysis to conduct curve fitting to capture the average conditions across a series of stratified plot data. The NLGY used a combination of 605 temporary sample plots (TSP) located within the park and nearby provincial Permanent Sample Plots (PSPs) and TSPs (2203 plots in all) of similar forest communities, given the lower number of park TSPs for some forest communities. The plot data used for yield projection were stratified by site productivity class (i.e., high-good, medium, and poor), forest community (i.e., white birch dominant, mixedwood dominant, softwood leading mixedwood dominant, balsam fir dominant, and spruce dominant forest communities) and ecoregion (i.e., northern and western).

\section{Forest inventory}

Accurate forest inventory information is the foundation for developing landscape-level forest management plans, forest monitoring, and environmental-policy development. In the spring of 2016, GMNP concluded a photointerpretation of aerial imagery acquired in 2010. The GMNP land base inventory based on this imagery was transferred into vector polygons with similar characteristics for both forested and nonforested areas. The forest polygons contained detailed information about tree species composition, age, height, site, and crown closure. This information was subsequently used to further stratify the forest landscape into dominant, forest species developmental types. Non-forest areas in GMNP included areas unsuitable for tree growth. These include bogs, barrens, and pooled surface water, rights-of-way for roads and transmission lines, as well as agricultural lands. Forest inventory interpretations were vetted against GMNP's own TSPs to ensure accuracy of specific forest traits like forest

Table 1. Six scenarios used to assess moose browsing and domestic harvest impacts on forest regeneration and development as well as the implementation of forest restoration programs that include moose population control and reforestation. Refer to main text for detailed descriptions.

\begin{tabular}{|c|c|c|c|c|c|}
\hline Scenario & Scenario name & Ruleset $^{1}$ & Browsing $^{2}$ & Harvesting $^{3}$ & Harvest Level $^{4}$ \\
\hline 1 & Light Browsing & Province & Light & No & - \\
\hline 2 & Heavy Browsing & GMNP & Heavy & No & - \\
\hline 3 & Light Browsing \& Harvest & Province & Light & Yes & Max. AAC \\
\hline 4 & Heavy Browsing \& Harvest & GMNP & Heavy & Yes & Max. AAC \\
\hline 5 & Light Browsing\& Harvest \& Planting & Province & Light & Yes & Max. AAC \\
\hline 6 & Heavy Browsing \& Harvest \& Planting & GMNP & Heavy & Yes & Max. AAC \\
\hline
\end{tabular}

\footnotetext{
${ }^{1}$ Source of yield and transition modelling information

${ }^{2}$ Level of moose browsing

${ }^{3}$ harvesting permitted

${ }^{4}$ Annual Allowable Cut - Maximum even flow sustainable harvest level
} 
development and productivity and successional trends. The interpretation was further enhanced to account for areas recently affected by widespread defoliation by insects, blowdown, and domestic harvesting.

\section{Modelling scenarios}

Six scenarios were formulated to assess forest development in the GMNP, including two realistic and four hypothetical scenarios representative of heavy to light moose browsing, sustainability of wood supply, and recovery of the forest ecosystem through moose population control and tree planting over a 100-year planning horizon (Table 1).

Scenario one assumed no harvesting and a light level of moose browsing concomitant with the current provincial moose population of two animals per $\mathrm{km}^{2}$. This density is comparable to that of surrounding forests adjacent to the park (McLaren et al. 2004), where hunting of moose is permitted by law (Mawhinney and Mahoney 1994). The hypothetical maximum annual allowable cut (AAC), within scenarios three through six, provides park managers with guidance of sustainable limits for equitable harvesting levels, while still allowing for effective ecosystem functioning and a target-level constraint that should not be exceeded without risking ecosystem decline. Maximum sustainable harvest levels are often controlled by past management practices which can be used to determine if ecosystem functioning has been negatively impacted by overharvesting.

\section{Data analysis}

Forest ecosystem integrity was evaluated by tracking the total growing stock, age class structure, changes in forest communities, and the amount of non-regenerating forest stands over time. Impacts of moose browsing, domestic harvesting, and tree planting were assessed by comparing changes in relative abundance of ecosystem indicators.

\section{Results and discussion}

The transition rules based on the regeneration surveys are shown in Table 2. Based on survey results, there were 33 and $45 \%$ of the surveyed areas in the western and northern ecoregions that fell into a category of not-sufficiently regenerated (NSR) compared with $10 \%$ in the provincial forests outside of the park (Table 2). Balsam fir and white birch stocking levels ranged from $21-28 \%$ and $24-26 \%$, respectively, for both ecoregions, followed by black spruce and white spruce (7-13\%), and lesser amounts of tamarack and red maple (1\%).

Modelled stocking level of balsam fir under heavy moose browsing is approximately a third of stocking levels observed under the light moose browsing scenario in areas adjacent to the park and represents nearly four times more total NSR area. Based on a previous study, about $40-60 \%$ stocking level in a young stand is required for the stand to be fully stocked when mature (Bergeron et al. 2011). We found GMNP balsam fir stocking levels (25\%) declined significantly when compared to provincial forests $(60 \%)$, while spruce stocking levels increased (Table 2). This observed change is consistent with previous studies which have shown tree species changes can arise at the landscape level because of acute herbivory by moose (Milligan and Koricheva 2013; Mathisen et al. 2017).

Our results indicate that the scenarios with light moose browsing consistently provided more tree volume through higher levels of total growing stock, leading to higher sustainable harvest levels, when compared against scenarios with heavy moose browsing (Fig. 2). These differences can be attributed to lower maximum volume estimates from the volume yield curves specific to the GMNP land base when compared to the yield curves adopted from a nearby provincial forest, where moose populations are actively managed (Fig. 3). This difference is evident in many instances where expected forest yields on good sites in heavily browsed areas can compare to volume estimates achieved on medium sites under light browsing. This is consistent with another study in the GMNP that concluded that lower volume estimates can be directly attributed to moose browsing owing to the fact that other natural disturbances (e.g., insect outbreaks) are typically applied evenly in forests both inside and outside of the park in western Newfoundland (Meades and Moores 1994). A study in Sweden (Kalen 2006) found that high browsing pressures by moose negatively impacted forest regeneration and volume growth, consistent with our own findings. Greater volume growth associated with light moose browsing led to elevated sustainable harvest levels (Figs. 2 and 3).

The levels of browsing and woodcutting impacts are also reflected in the relative changes in species composition and distribution throughout the park between lightly- and heav-

Table 2. GMNP-specific transition rules derived from 2005 and 2016 regeneration-survey data, displaying the percent abundance of each species expected to regenerate following stand succession in a heavy browsing scenario. The provincial transition rules were used for the light moose browsing scenario because of the relatively low population density of moose in the provincial forest outside GMNP, which results from long-term moose population control by the province. It is assumed that GMNP will transition to the light moose browsing scenario as moose population densities are reduced through Parks Canada's recently-launched moose population control program.

\begin{tabular}{|c|c|c|}
\hline Source & Ecoregions & Regenerating Species (\%) \\
\hline GMNP & $\begin{array}{l}\text { Northern } \\
\text { Western }\end{array}$ & $\begin{array}{l}\mathrm{bF}(21), \mathrm{bS}(3), \mathrm{tL}(1), \mathrm{wB}(26), \mathrm{wS}(4), \operatorname{NSR}(45) \\
\mathrm{bF}(28), \mathrm{bS}(3), \mathrm{rM}(1), \mathrm{wB}(24), \mathrm{wS}(10), \operatorname{NSR}(33)\end{array}$ \\
\hline Province & Both & bF(60), bFsP(10), MSW(15), MHW(3), wB(2), NSR(10) \\
\hline
\end{tabular}



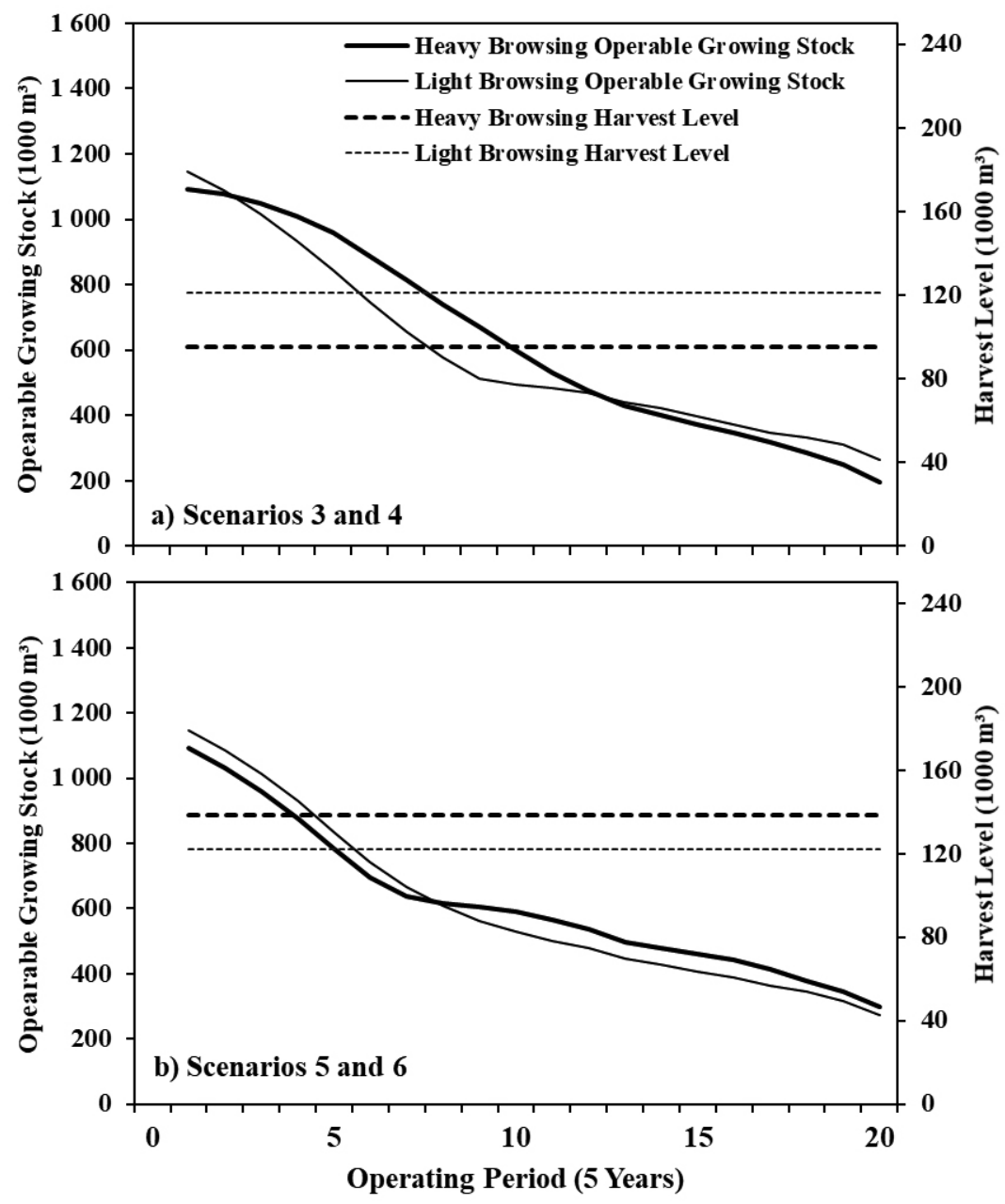

Fig. 2 Predicted changes in operable growing stock and harvest level through time under the impact of moose browsing with maximum sustainable domestic harvest for each scenario. Subfigure a) displays the impact of light (scenario three) and heavy (scenario four) moose browsing, subfigure b) shows the impact of light (scenario five) and heavy (scenario six) moose browsing and planting for each scenario.

Table 3. Contribution of bF, sP, and wB to the total harvest level $\left(\mathrm{m}^{3}\right)$ for the western and the northern ecoregions under scenarios 3-6 that explored the impacts of light and heavy moose browsing pressures, with the addition of maximum sustainable level for the domestic harvest program (scenarios 3 and 4) and tree planting strategies (scenarios 5 and 6) in GMNP.

\begin{tabular}{|c|c|c|c|c|c|c|c|c|}
\hline \multirow{3}{*}{$\begin{array}{l}\text { Species (Region) } \\
\text { bF (West) }\end{array}$} & \multicolumn{2}{|c|}{ Scenario 3} & \multicolumn{2}{|c|}{ Scenario 4} & \multicolumn{2}{|c|}{ Scenario 5} & \multicolumn{2}{|c|}{ Scenario 6} \\
\hline & \multicolumn{2}{|c|}{$\begin{array}{c}\text { Light Browsing } \\
\text { \& Harvest }\end{array}$} & \multicolumn{2}{|c|}{$\begin{array}{c}\text { Heavy Browsing } \\
\text { \& Harvest }\end{array}$} & \multicolumn{2}{|c|}{$\begin{array}{l}\text { Light Browsing \& } \\
\text { Harvest \& Planting }\end{array}$} & \multicolumn{2}{|c|}{$\begin{array}{l}\text { Heavy Browsing \& } \\
\text { Harvest \& Planting }\end{array}$} \\
\hline & 1312542 & $(79 \%)$ & 896916 & $(76 \%)$ & 1344416 & $(79 \%)$ & 721106 & $(71 \%)$ \\
\hline sP (West) & 310100 & $(69 \%)$ & 406129 & $(62 \%)$ & 341311 & $(77 \%)$ & 1162448 & $(78 \%)$ \\
\hline wB (West) & 147576 & $(74 \%)$ & 187845 & $(76 \%)$ & 141292 & $(75 \%)$ & 135093 & $(73 \%)$ \\
\hline sP (North) & 140780 & $(31 \%)$ & 153166 & $(38 \%)$ & 100493 & $(23 \%)$ & 331387 & $(22 \%)$ \\
\hline bF (North) & 353407 & $(21 \%)$ & 285599 & $(24 \%)$ & 357381 & $(21 \%)$ & 292050 & $(29 \%)$ \\
\hline wB (North) & 51517 & $(26 \%)$ & 60065 & $(24 \%)$ & 47580 & $(25 \%)$ & 51202 & $(27 \%)$ \\
\hline
\end{tabular}

$\mathrm{bF}=$ balsam fir; $\mathrm{SP}=$ spruce; $\mathrm{wB}=$ white birch 

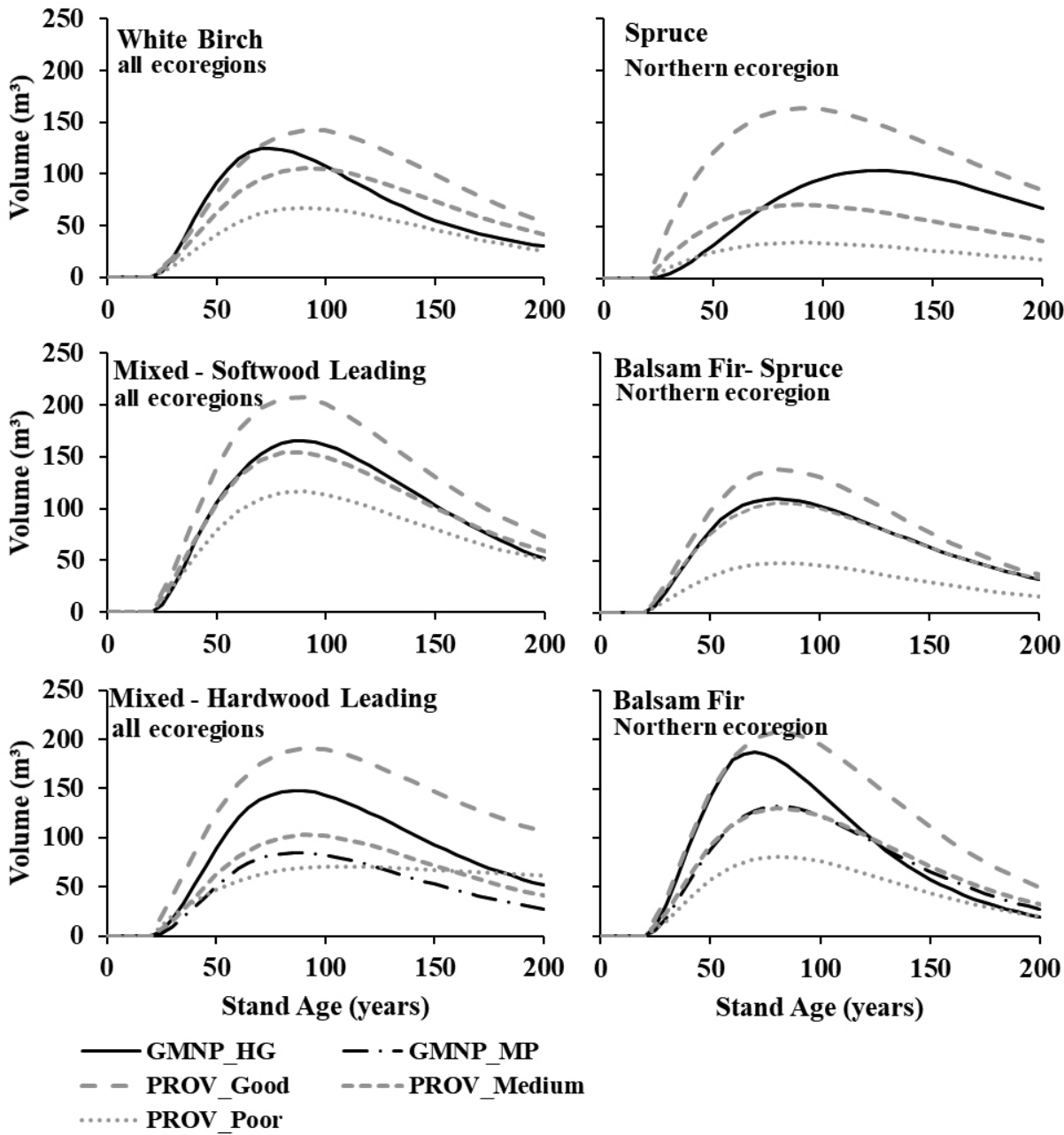

Fig. 3 Comparison of strata-based GMNP yield curves on high to good (HG) sites and medium to poor (MP) sites versus existing provincial yield curves on good, medium and poor sites. GMNP-based yield curves were generated from a combination of GMNP TSP and Provincial PSP and TSP data for ecoregions intersecting with park boundaries.

ily-browsed areas. Balsam fir-dominated areas increased with light browsing and decreased with heavy browsing. Likewise, areas with balsam fir-spruce forests decreased under light browsing, compared to heavy browsing (Figs. 4 and 5). Spruce-dominated stands tended to increase for both heavy and light moose browsing, with an expanded distribution and occurrence of spruce under heavy-browsing conditions (Figs. 4 and 5). A net result from heavy browsing is a reduction in balsam fir, accompanied by a significant increase in spruce-dominated stands. This is consistent with findings of a field study conducted in the GMNP which found largescale changes in forest composition driven by suppression of balsam fir regeneration by moose and other non-native herbivores, including red squirrels (Tamiasciurus hudsonicus Erxlebren) and snowshoe hares (Lepus americanus Erxlebren; Gosse et al. 2011).
Browsing impacts on balsam fir were also observed in other national parks in eastern Canada. For example, a study in Isle Royale National Park revealed significant reduction in fir-dominated stands due to browsing by moose (Snyder and Janke 1976). Severe browsing damage caused by white tail deer on Anticosti Island has led to a prediction of complete balsam fir removal over the long-term (Potvin et al. 2003). Low regeneration rates in balsam fir-dominated forests due to moose browsing has been documented in Cape Breton Highlands National Park (Smith et al. 2015).

Age-class distributions can be used to evaluate forest ecosystem sustainability (Garet et al. 2012). Expanding the age-class structure of a forest, including old-age stands, can improve wildlife conservation efforts by providing favourable habitat for all types of wildlife (Thompson and Curran 1995; Didion and Fortin 2007; Zhu et al. 2010). In this study, old 

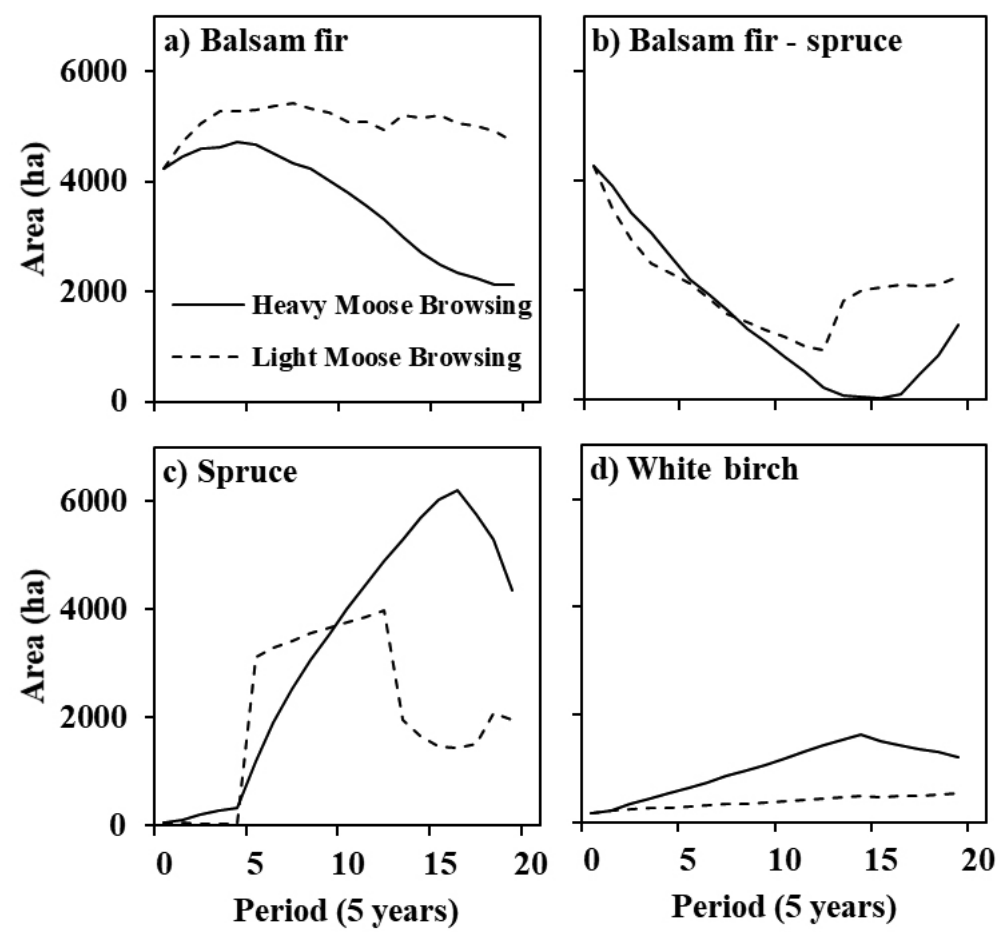

Fig. 4 Modeled change in area of balsam fir, balsam fir-spruce, spruce and white birch forests under scenarios three (light moose browsing) and four (heavy moose browsing) with domestic harvesting set at a maximum sustainable level for each scenario.

growth forest was predicted to increase in the northern ecoregion, but decrease in the western ecoregion for both light and heavy moose browsing (Fig. 6). Model results indicate more harvesting activities occur in the western ecoregion than in the northern ecoregion, which could account for differences in predicted old growth forests (Figs. 2 and 6). Another possible explanation for the increase in old growth forests in the northern ecoregion is a greater proportion of less palatable spruce stocking compared to the western ecoregion, leading to a lower overall projected impact by moose (Figs. 4, 5, and 6). The difference between balsam fir and spruce is not believed to impact the coverage of old growth forests much, since both species follow very similar developmental patterns (Farrar 1995). The increased regeneration success of spruce, when compared to balsam fir, would allow more spruce-dominated stands to reach old age (Figs. 4, 5, and 6).

Planting was suggested as a tool for park managers to improve regeneration success within the park and to combat the lower regeneration success rates caused by heavy moose browsing (Humber 2009; Gosse et al. 2011). In this model, the action of planting balsam fir to maintain species balance in the GMNP was initially explored but abandoned, with the consideration that any investment in planting within the park with a species that is palatable to moose would not be a sound investment until such time that the hyper-abundance of moose is controlled. Instead, the planting action of spruce in the model is to target areas designated as NSR, based on local forest industry's successes in planting spruce, which grows well in the presence of moose but regenerates poorly in natural conditions. The simulated results of the planting improved operable growing stock (OGS) and harvest levels, and helped to balance age-class stand structure in heavily browsed areas, reducing NSR areas within the park. This same planting action had nominal impact in lightly browsed areas (Figs. 2, 5-7). While planting spruce increased harvest and OGS levels in both light and heavy browsing scenarios, planting produced greater amounts in both measures for the heavily browsed scenario (Fig. 2). This counterintuitive result was directly related to heavily browsed areas having more NSR areas available for planting when compared to lightly browsed areas. Increased planting in heavily browsed areas produced greater OGS levels than in the lightly browsed areas (volume $=296318$ vs. $271122 \mathrm{~m}^{3}$, respectively) at the landscape level by the end of the planning horizon. Higher OGS levels tended to enable higher maximum harvest levels of $138511 \mathrm{~m}^{3}$ in the heavy browsing and planting scenario, compared to 122194 $\mathrm{m}^{3}$ in the light browsing scenario (Fig. 2).

Planting can help establish forest cover, but at high moose densities planting spruce can accelerate stand conversion to spruce-dominated stands. It will remain a significant challenge for park managers to maintain current species balance, plantation area sizes, and to meet expenditures associated with planting. In heavily browsed areas, assuming a planting cost of $\$ 580$ ha $^{-1}$ (Robert Sutton, DNR personal communication, 2016), it would require $\$ 941340$ for each 5-year period to treat 1625 ha. By provincial and industrial forestry standards, planted area sizes are mostly small. However for parks, this would be too costly, especially when coupled with road inaccessibility to most of park forests, which would increase the cost of planting. Indeed, Cape Breton Highlands National Park managers investigated a similar option of planting disturbed areas, even establishing small-scale plantations, but concluded that landscape-level planting would be largely cost prohibitive (Smith et al. 2015).

Species distribution patterns under scenarios of heavy and light browsing, combined with planting, did not vary much beyond the results found with the scenarios without planting. The only difference between scenarios was in the rate at which stand conversion could occur. Heavy browsing and planting resulted in more spruce-dominated stands across the forested landscape, nearly doubling that projected for light browsing. Under light browsing, requirement of planting was generally less, resulting in more total balsam fir- and balsam fir and spruce-dominated stands residing on the land base (Figs. 4 and 5). 

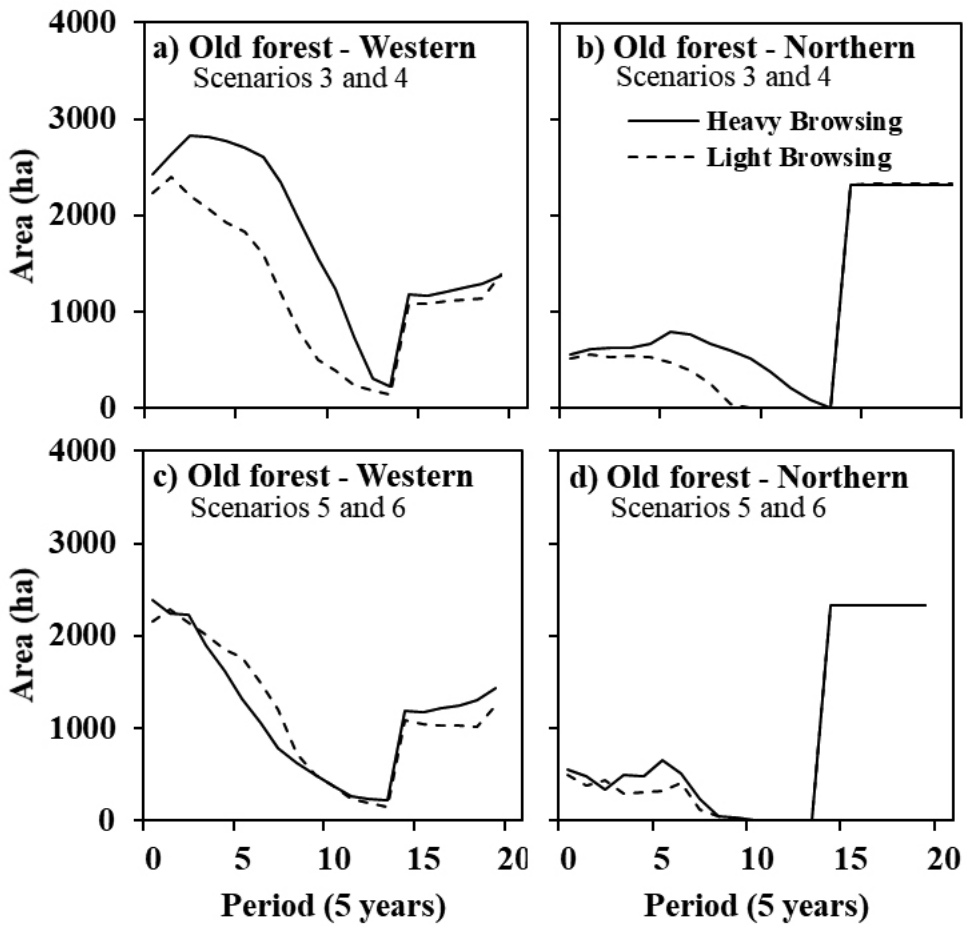

Fig. 6 Figures representing the predicted area of the old-age ( 80 years or older) forests through time within the northern and western ecoregions with domestic harvesting set at a maximum sustainable level for each scenario. Subfigures (a) and (b) explored the impacts of light and heavy moose browsing pressures within the two ecoregions. Subfigures (c) and (d) explored the impacts of light and heavy moose browsing pressures within the two ecoregions with the addition of planting spruce hundreds of resampling simulations. Regretfully, the NL yield tool lacks some key features that would allow us to conduct parameter uncertainly analysis (e.g., batch processing of datasets out of resampling simulations and integration with third party applications for estimating confidence interval of parameters). Nevertheless, our concerns related to scientific uncertainty in the development of NL yield curves will serve to inform forest managers and decision-makers, so that it can incite local industry to search for a solution to incorporating parameter uncertainty analysis into the NL yield curve development.

Other uncertainties that are critical to the success of future forest yield modeling are impacts of climate change on forest growth and productivity. As it is known, development and calibration of "conventional" forest G\&Y models are based on the assumption that future forest growth conditions will be similar to the past. However, growing evidence indicates that tree growth conditions (light, water, temperature, and site nutrient) have changed and will continue to change significantly in the future (Boisvenue and Running 2006; Girardin et al. 2011; Price et al. 2013), imposing not just negative impacts to forest development but also positive growth effects on boreal forests $\left(\mathrm{CO}_{2}\right.$ fertilization and longer growing seasons). Under such circumstances, the "conventional" forest G\&Y models used to project yield curves become uncertain and provide users with very few options in development and implementation of adaptive management strategies. Thus, further efforts are needed to incorporate climate change scenarios into forest yield projection to support adaptive forest management under climate change.

\section{Concluding remarks}

Heavy moose browsing pressure on preferred balsam fir within GMNP resulted in a drastic increase in the not-sufficiently regenerated (NSR) area. Heavy moose browsing damage to the park's balsam-dominated forest has the potential to cause a long-term reduction in total growing stock volume of balsam fir and a shift of forest structure in species composition, such as the transition of mixed balsam fir-spruce stands to purely spruce-dominated stands. Under such circumstance, forest restoration in the park may be achieved through moose population management aimed to lower population density to the level in the surrounding forest outside the park. In addition, planting when combined with moose population management could help accelerate the recovery of forest structure and ecological functions in GMNP. 

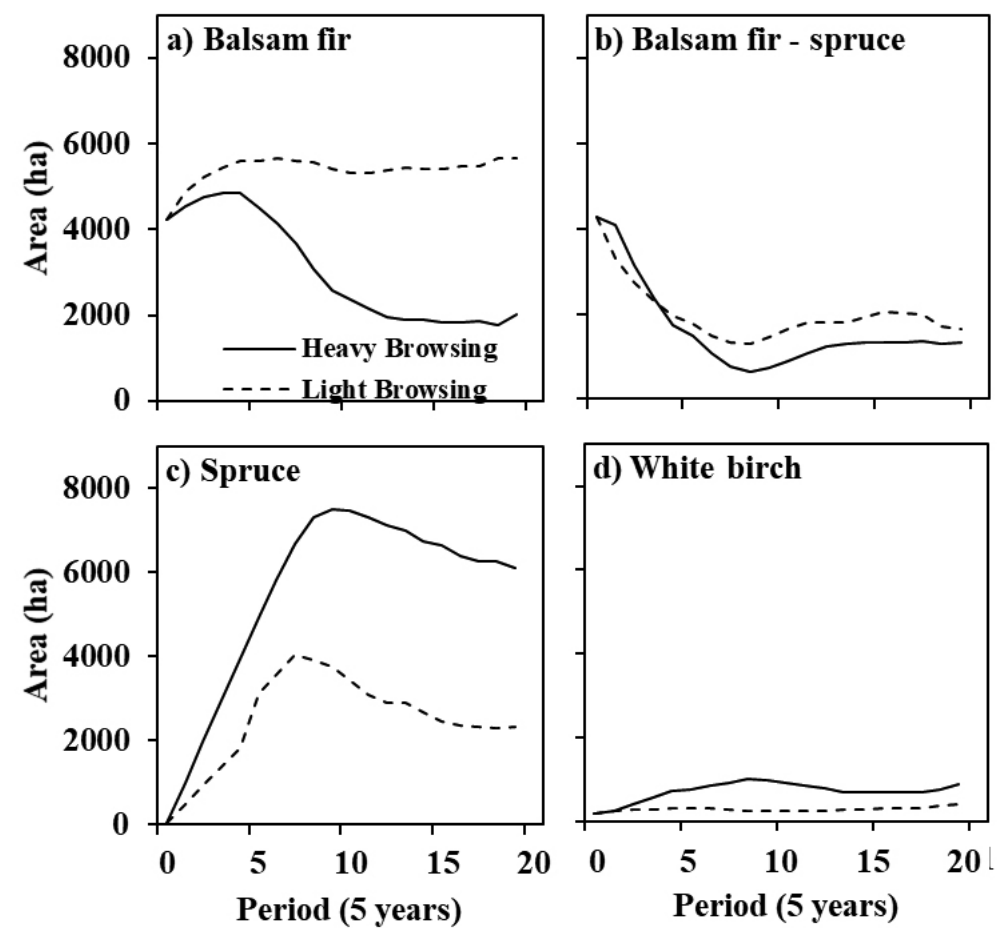

Fig. 5 Modeled area of balsam fir, balsam fir-spruce, spruce and white birch forests under scenarios five and six to evaluate recovery of forest integrity through tree planting as a means to improve forest regeneration over the long term. Scenario five assumed light moose browsing coupled with domestic harvesting and planting, whereas scenario six assumed heavy moose browsing, domestic harvesting, and planting.

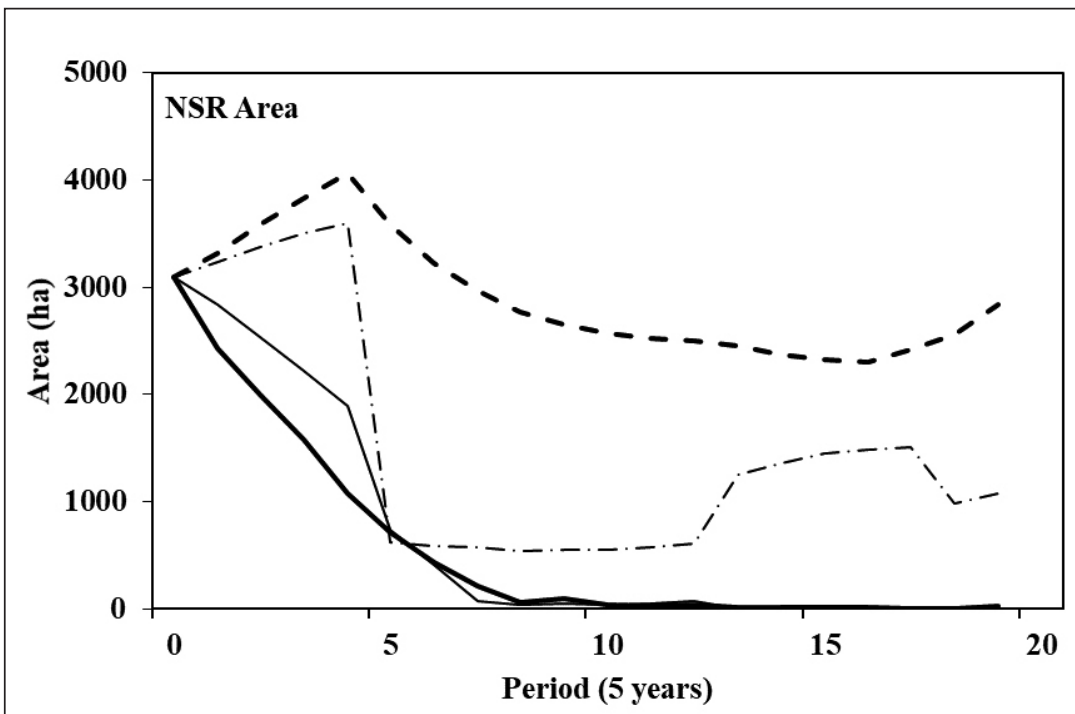

- - Scenario 3 Light Browsing - - Scenario 4 Heavy Browsing Scenario 5 Light Browsing Scenario 6 Heavy Browsing

.Fig. 7 Non-sufficiently regenerated (NSR) area under scenarios 3 and 4 exploring the impacts of light and heavy moose browsing pressures, with the addition of domestic harvesting set at a maximum sustainable level for each scenario, and scenarios 5 and 6 for similar conditions with the addition of planting spruce.

\section{Acknowledgements}

We thank Dr. Tom Knight of Gros Morne National Park for his prompt and constructive review of an initial draft of this manuscript. Special thanks also go to Canadian Forest Service, particularly Gordon Butt and Rebekka Stone, and the Department of Natural Resources (Robert Sutton) who provided expertise and research direction.

\section{References}

Bergeron, Y. and A. Leduc. 1998. Relationships between change in fire frequency and mortality due to spruce budworm outbreaks in the southern Canadian boreal forest. J. Veg. Sci. 9(4): 492-500. doi:10.2307/3237264

Bergeron, D. H., P.J. Pekins, H.F. Jones and W.B. Leak. 2011. Moose browsing and forest regeneration: a case study in northern New Hampshire. Alces 47: 39-51.

Boisvenue C. and S.W. Running. 2006. Impacts of climate change on natural forest productivity. Glob. Change. Biol. 12(5): 862882. doi: 10.1111/j.1365-2486.2006.01134.x

Bouchard, M., D. Kneeshaw and Y. Bergeron. 2005. Mortality and stand renewal patterns following the last spruce budworm outbreak in mixed forests of western Quebec. For. Ecol. Manage, 204(2-3): 297-313. doi: 10.1016/ j.foreco.2004.09.017

Caines, P. and H. Deichmann. 1989. Resource Description and Analysis; Gros Morne National Park. Rocky Harbour, NL: Env. Canada, Unpublished Report.

Cieszewski, C., M. Zasada, B. Borders, R. Lowe, J. Zawadzki, M. Clutter and R. Daniels. 2004. Spatially explicit sustainability analysis of long-term fiber supply in Georgia, USA. For. Ecol. Manage. 187: 349-359. doi: 10.15684/formath.001

Conedera, M., D. Torriani, C. Neff, C. Ricotta, S. Bajocco and G.B. Pezzatti. 2011. Using Monte Carlo simulations to estimate relative fire ignition danger in a low-tomedium fire-prone region. Forest Ecol. Manag. 26: 2179-2187. doi: 10.1016/j.foreco. 2010.08.013

Connor, K. J., W.B. Ballard, T. Dilworth, S. Mahoney and D. Anions. 2000. Changes in structure of a boreal forest community following intense herbivory by moose. Alces 36 : 111-132.

Didion, M. and M.-J. Fortin. 2007. Forest age structure as indicator of boreal forest sustainability under alternative management and fire regimes: A landscape level sensitivity analysis. Ecol. Model. 200: 45-58. doi: 10.1016/j.ecolmodel.2006.07.011

Department of Natural Resources. 1993. Newfoundland and Labrador Regeneration Assessment Procedures, Unpublished Report. Engelmark, O. 1999. Boreal forest disturbances. In: L. Walker, Ecosystems of the World, vol. 16. Ecosystems of Disturbed Ground (pp. 161-186). Amsterdam, The Netherlands: Elsevier Science. 
Farrar, J.L. 1995. Trees in Canada. Nat. Res. Can., Can. For. Serv. and Fitshenr and Whiteside, Ottawa.

Furgeuson, S. H. and F. Messier. 1996. Can human predation of moose cause population cycles? Alces 32: 149-161.

Garet, J., F. Raulier, D. Pothier and S. Cumming. 2012. Forest age class structures as indicators of sustainability in boreal forest: Are we measuring them correctly? Ecol. Indic. 23: 202-210. doi:10.1016/ j.ecolind.2012.03.032

Girardin, M.P., P. Y. Bernier, F. Raulier, J.C. Tardif, F. Conciatori and X.J. Guo. 2011. Testing for a $\mathrm{CO}_{2}$ fertilization effect on growth of Canadian boreal forests. J. Geophys. Res-Biogeo. 116 (G1). doi: 10.1029/2010/G001287.

Gosse, J., L. Hermanutz, B. McLaren and T. Knight. 2011. Degradation of boreal forest by non-native herbivores in Newfoundland's National Parks: Recommendations for ecosystem restoration. Natural Areas J. 31: 331-339. doi: 10.3375/043.031.0403

Government of Canada. 2010. Canada National Parks Act. (SC2000, C. 32) No. 14-01. Ottawa.

Gustafson, E. J. and T. R. Crow. 1996. Simulating the effects of alternative forest management strategies on landscape structure. J. Env. Manage. 46: 77-94.

Hobbs, N. T., D. S. Schimel, C. E. Owensby and D. S. Ojima. 1991. Fire and grazing in the tallgrass prairie: Contingent effects on nitrogen budget. Ecology 72:1374-1382.

Humber, J. 2009. Non-native plant invasions of boreal forest gaps: Implications for stand regeneration in a protected area shaped by hyper abundant herbivores. M.S. thesis, Department of Biology, Memorial University of Newfoundland, St. John's.

Janes, G. 1976. Moose and Caribou census of Gros Morne Nat. Park. Rocky Harbour: Parks Canada.

Jeffries, R. L., A. Jensen and K. F. Abraham. 1979. Vegetational development and the effect of geese on vegetation at La Perouse Bay, Manitoba, Canada. Can. J. Bot. 57: 1439-1450.

Kalen, C. 2006. Deer browsing and impact on forest development. J. Sustain. Forest. 21: 53-64. doi: 10.1300/J091v21n02_04

Mathisen, K.M. J.M. Milner and C. Skarpe. 2017. Moose-tree interactions: Rebrowsing is common across tree species. BMC Ecol. 17: 12 1-15. doi: 10.1186/s12898-017-0122-3

Mawhinney, K. and S. P. Mahoney. 1994. Aerial moose census of management units 5, 6 and 7 in Western Newfoundland Model Forest, 1993 and 1994. Corner Brook, NL: Western Newfoundland Model Forest.

McCarthy, C. 2000. Gros Morne Domestic Timber Harvest Information Newsletter.

McCarthy, J.W. and G. Weetman. 2007. Stand structure and the development of an insect-mediated boreal forest landscape. For. Ecol. Manage. 241: 101-114. doi: 10.1016/j.foreco.2006.12.030

McLaren, B. E., B. A. Roberts, N. Djan-Chekar and K. P. Lewis. 2004. Effects of overabundant moose on Newfoundland landscape. Alces 40: 45-59.

McLaren, M. E., S. Taylor and S. H. Luke. 2009. How moose select forested habitat in Gros Morne National Park. Alces 45: 125-135.

McNaughton, S. J. 1979. Grassland-herbivore dynamics. In: A. R. Sinclaire and M. Norton-Griffins, Serengeti: Dynamics of an ecosystem, pp. 46-81. Chicago, Illinois: University of Chicago Press.

Meades, W. and L. Moores. 1994. Forest site classification manual: A field guide to the Damman forest types of Newfoundland. Second edition. Western Newfoundland Model Forest, Inc; Dept. For Agric; Nat. Res. Can., Can. For. Serv., Forest Resources Development Agreement FRDA Rep. 003.

Milligan, H.T and J. Koricheva. 2013. Effects of tree species richness and composition on moose winter browsing and foraging selectivity: An experimental study. J. Anim. Ecol. 82: 739-748. doi: 10.1111/1365-2656.12049

Murie, A. 1934. The moose of Isle Royale. Anne Arbor, MI: Mus. Zool., Univ. Mich., Misc. Publ. 25.
Parks Canada. 2005. Park backgrounder: Gros Morne National Park of Canada. Retrieved from In Special places: Eco-lessons from the national parks in Atlantic Canada. Parks Canada: www.pc.gc.ca/ apprendre-learn/prof/sub/eco/itm5/fi-lr1/gros-morne_e.asp

Paster, J., R. A. Moen and Y. Cohen. 1997. Spatial heterogeneities, carrying capacity, and feedbacks in animal landscape interactions. J. Mammal. 78: 1040-1052.

Pimlott, D. H. 1953. Newfoundland Moose. Trans. N. A. Wild. Conf. 18: 563-581.

Pimlott, D. H. 1959. Reproduction and productivity of Newfoundland Moose. J. Wildlife Manage. 23: 381-401.

Potvin, F., P. Beaupre and G. Laprise. 2003. The eradication of balsam fir by white-tailed deer on Anticosti Island, Quebec: A 150-year process. Ecoscience 10(4): 487-495.

Pretzch, H., R. Grote, B. Reineking, T. Rotzer and S. Seifert. 2008. Models for forest ecosystem management: A European perspective. Ann. Bot. 101: 1065-1087.

Price, D.T., R. I. Alfaro, K. J. Brown, M.D. Flannigan and R. A. Fleming et al. 2013. Anticipating the consequences of climate change for Canada's boreal forest ecosystems. Environ. Rev. doi: 10.1139/er-2013-0042

Remsoft. 2016. Spatial Woodstock user guide. Fredericton, NB: Remsoft Inc.

Rinaldi, F. and R. Jonsson. 2020. Accounting uncertainty in forest management models. Forest Ecol. Manag. 468: 118186. doi: 10.1010/j.foreco.2020.118181

Shifley, S.R., S.H. Hong, H. Lischke, W.J. Wang, J. Wenchi and E.J. Gustafson et al. 2017. The past and future of modeling forest dynamics: from growth and yield curves to forest landscape models. Landscape Ecol. 32: 1307-1325. doi: 10.1007/s10980-017-0540-9

Smith, R., M. Smith, P. Clifford and C. Bellemore. 2015. Hyperabundant Moose Management Plan for North Mountain, Cape Breton Highlands National Park. Ingonish Beach, NS: Parks Canada Agency.

Snyder, J. D. and R. A. Janke. 1976. Impact of moose browsing on boreal-type forests of Isle Royale National Park. Am. Midl. Nal. 95(1): 79-92.

Sy, K., K. Keenleyside, B. Adare, B. Reader and P. Deering. 2009. Protecting native biodiversity from high-impact invasive species through the protected areas of Parks Canada. Biodiversity 10: 51-55. doi: 10.1080/14888386.2009.9712843

Taylor, E. 1991. Gros Morne National Park Aerial Moose Survey. Rocky Harbour: Parks Canada.

Thompson, I.D. and W.J. Curran. 1995. Habitat suitability for marten of second growth balsam fir forests in Newfoundland. Can. J. Zool. 73: 2059-2064.

Thompson, R. 2007. Gros Morne National Park Aerial moose survey. Rocky Harbour, NL: Parks Canada.

Tomppo, E., H. Olsson, G. Stahl, M. Nilsson, O. Hagner and M. Katila. 2008. Combining national forest inventory field plots and remove sensing data for forest databases. Remote Sens. Environ. 112: 1982-1999. doi: 10.3390/rs70100378

Tong, L., C. Chang, S. Jin and R. Saminathan. 2012. Quantifying uncertainty of emission estimates in National Greenhouse Gas Inventories using bootstrap confidence intervals. Atmos. Environ. 56: 80-87. doi: 10.1016/j.atmosenv.2012.03.063

Vanclay, J. 2002. Forest Growth and Yield Modeling. In: ElShaarawi, A., Piegorsch, W. (Eds) Encyclopaedia of Environmetrics (pp. 811-812). NY: Wiley.

Weiskittel, A.R., D.W. Hann, J.A. Kershaw and J.L. Vanclay. 2011. Forest growth and yield modeling. Chap. 5. Tree-level models (pp. 69-84). John Willey \& Sons, Ltd. doi. 10.1002/9781119998518 Zhu, X., C.P. Bourque, S. Taylor, R. Cox and C. Wentzell. 2010. Predicting the effects of woodcutting and moose browsing on forest development in Gros Morne National Park, Newfoundland, Canada. Forest. Chron. 86: 178-192. doi: 10.5558/tfc86178-2 